\title{
Crosstalk Between Mast Cells and Adipocytes in Physiologic and Pathologic Conditions
}

\author{
Daniel Elieh Ali Komi ${ }^{1,2} \cdot$ Farzaneh Shafaghat $^{1,2} \cdot$ Mark Christian $^{3}$
}

Published online: 25 March 2020

(C) The Author(s) 2020

\begin{abstract}
Excessive fatty acids and glucose uptake support the infiltration of adipose tissue (AT) by a variety of immune cells including neutrophils, pro-inflammatory M1 macrophages, and mast cells (MCs). These cells promote inflammation by releasing proinflammatory mediators. The involvement of MCs in AT biology is supported by their accumulation in the AT of obese individuals along with significantly higher serum levels of MC-derived tryptase. AT-resident MCs under the influence of locally derived adipokines such as leptin become activated and release pro-inflammatory cytokines including TNF $\alpha$ that worsens the inflammatory state. MCs support angiogenesis in AT by releasing chymase and inducing preadipocyte differentiation and also the proliferation of adipocytes through 15-deoxy-delta PGJ2/PPAR $\gamma$ interaction. Additionally, they contribute to the remodeling of the AT extracellular matrix (ECM) and play a role in the recruitment and activation of leukocytes. MC degranulation has been linked to brown adipocyte activation, and evidence indicates an important link between MCs and the appearance of BRITE/beige adipocytes in white AT. Cell crosstalk between MCs and AT-resident cells, mainly adipocytes and immune cells, shows that these cells play a critical role in the regulation of AT homeostasis and inflammation.
\end{abstract}

Keywords Adipocyte $\cdot$ Adipose tissue $\cdot$ Inflammation $\cdot$ Mast cell

\begin{tabular}{ll}
\multicolumn{2}{l}{ Abbreviations } \\
AT & Adipose tissue \\
BMMC & Bone marrow-derived mast cells \\
HFD & High-fat diet \\
IR & Insulin resistance \\
MC & Mast cell \\
MCP-1 & Monocyte chemoattractant protein-1 \\
PPAR $\gamma$ & Peroxisome proliferator-activated receptor-gamma \\
T2D & Type 2 diabetes \\
WAT & White adipose tissue \\
VEGF & Vascular endothelial growth factor \\
bFGF & Basic fibroblast growth factor
\end{tabular}

Mark Christian

mark.christian@ntu.ac.uk

1 Immunology Research Center, Tabriz University of Medical Sciences, Tabriz, Iran

2 Department of Immunology, Tabriz University of Medical Sciences, Tabriz, Iran

3 School of Science and Technology, Nottingham NG11 8NS, UK

\section{Introduction}

Adipose tissue (AT) acts not only as an energy depot and regulator of energy homeostasis but also as an active endocrine organ capable of producing hormones and adipokines including leptin, adiponectin, TNF- $\alpha$, IL-1 $\beta$, IL-6, IL- 8 , and monocyte chemotactic protein-1 (MCP-1), [1, 2]. Obesity is accompanied by the accumulation of immune cells in AT after which they promote inflammation and negatively influence systemic metabolism [1]. Hyperplasia and hypertrophy of AT are two common findings during obesity through which AT expands in size [3]. Hypertrophy of adipocytes surrounded by a rigid extracellular matrix (ECM) causes physical pressure on the vasculature system that disturbs the blood flow of the tissue to promote inflammation and fibrosis [4]. Additionally, perivascular AT reduces arterial contraction by releasing perivascular-derived relaxation factors [5]. Alteration of AT residing cells during obesity has been well documented in which neutrophils, pro-inflammatory M1 macrophages, and mast cells (MCs) accumulate while populations including Th2, Treg, and eosinophils (populations that support antiinflammatory responses and immunoregulation) are decreased [1] (Fig. 1). The bridging of inflammation and immunometabolism was highlighted by Hotamisligil et al. in 


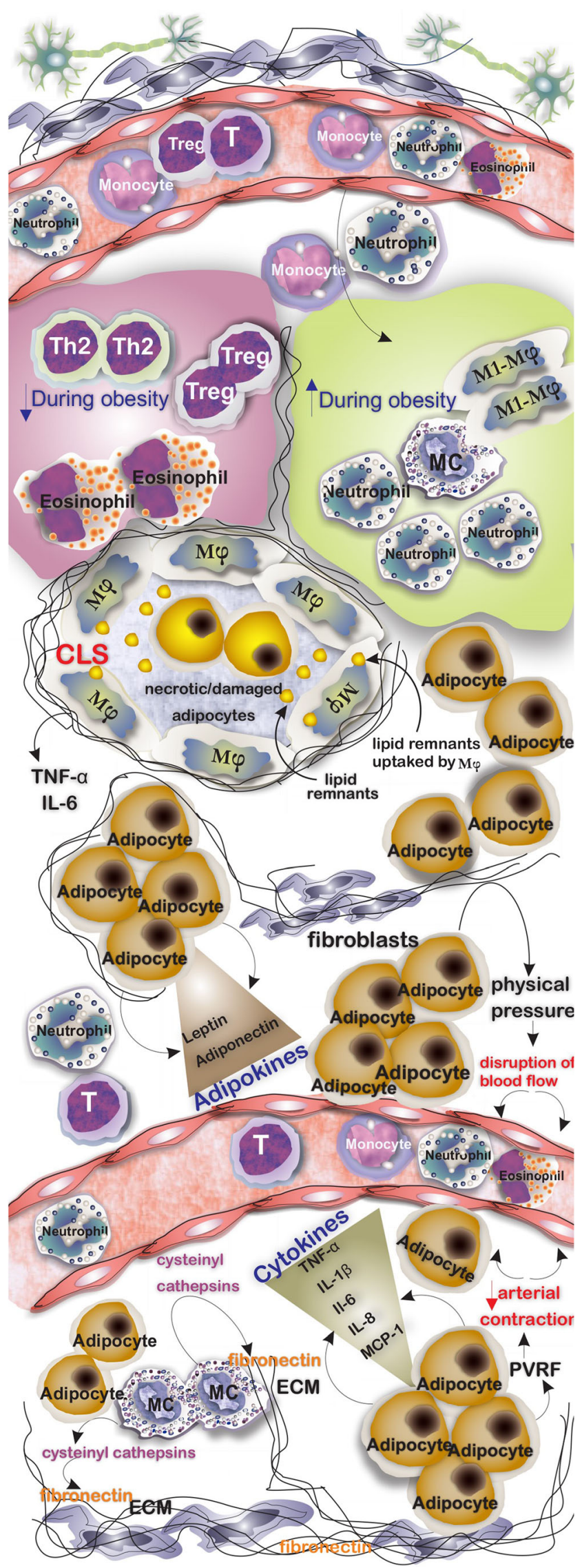

Fig. 1 Adipocytes are the main cell population in AT. However, several types of cells are commonly found in AT which their number varies in lean and obese AT, for example, while the number of M1 macrophages, MCs, and neutrophils increases in obesity, the number of AT resident Th2, Treg, and eosinophils decreases. AT in obesity is infiltrated by inflammatory cells, and the formation of crown-like structures characterized by circled necrotic/damaged adipocytes with macrophages is a common finding. Adipocytes not only store lipids but also release several cytokines and adipokines that influence immune responses and hemostasis of the tissue. An increase in number and the size of adipocytes surrounding the vasculature system results in the formation of physical pressure and consequent disruption of blood flow. MCs through inducing the release of cysteinyl cathepsins from endothelial and adipocytes play a role in catabolizing fibronectin

1993, by showing that TNF- $\alpha$ has elevated levels in obese fa/ fa rats and its neutralization by a recombinant TNFR-IgG chimeric protein resulted in a marked increase in peripheral insulin-dependent uptake of glucose [6]. Investigations in humans then confirmed these findings. Elevated levels of TNF- $\alpha$ in obese individuals were shown to reduce during weight loss [7].

An increasing number of researchers have reported the accumulation of MCs in AT of obese individuals [8, 9]. MCs stimulate the release of cysteinyl cathepsins from vascular cells and adipocytes to catabolize ECM protein fibronectin to support adipogenesis [10]. Intraperitoneal injection of disodium cromoglycate (DSCG; a widely used inhibitor of MC activation and degranulation) of wild-type (WT) mice was reported to hamper the ability to gain body weight [11]. Interestingly, recent investigations linked the positive effects of traditional foods such as Chinese bitter melon and quercetin (a bioflavonoid found in dietary plants) with the capability of reducing body weight gain and insulin resistance (IR) to MC in which using such foods reduces the infiltration of MCs in AT and prevents the formation of an inflammatory microenvironment $[12,13]$. Having a molecular understanding of the crosstalk between AT resident and infiltrated cells including monocytes and macrophages may shed light on better treatment of obesity and related diseases such as IR and diabetes.

\section{Mast Cell Origin, Development, and Function}

MCs are cells of innate immunity that reside in tissues including AT and produce a range of pro-inflammatory cytokines [14]. They are granular long-lived cells that develop from CD34+/CD117+ pluripotent progenitor cells. These precursors, after being released from the bone marrow into the circulation, reach different target organs through chemokine and integrin-dependent trafficking $[15,16]$. The progenitors under the influence of growth factors, mainly stem cell factor (SCF), differentiate and mature into functional MCs expressing FceRI [17]. IgE-FceRI interaction accounts for the main MC activation pathway through which MC degranulation occurs 
IL-1R, IL-3R,TGFßR

IL-10R, IL-12R, INFYR, CO-STIMULATORY MOLECULES
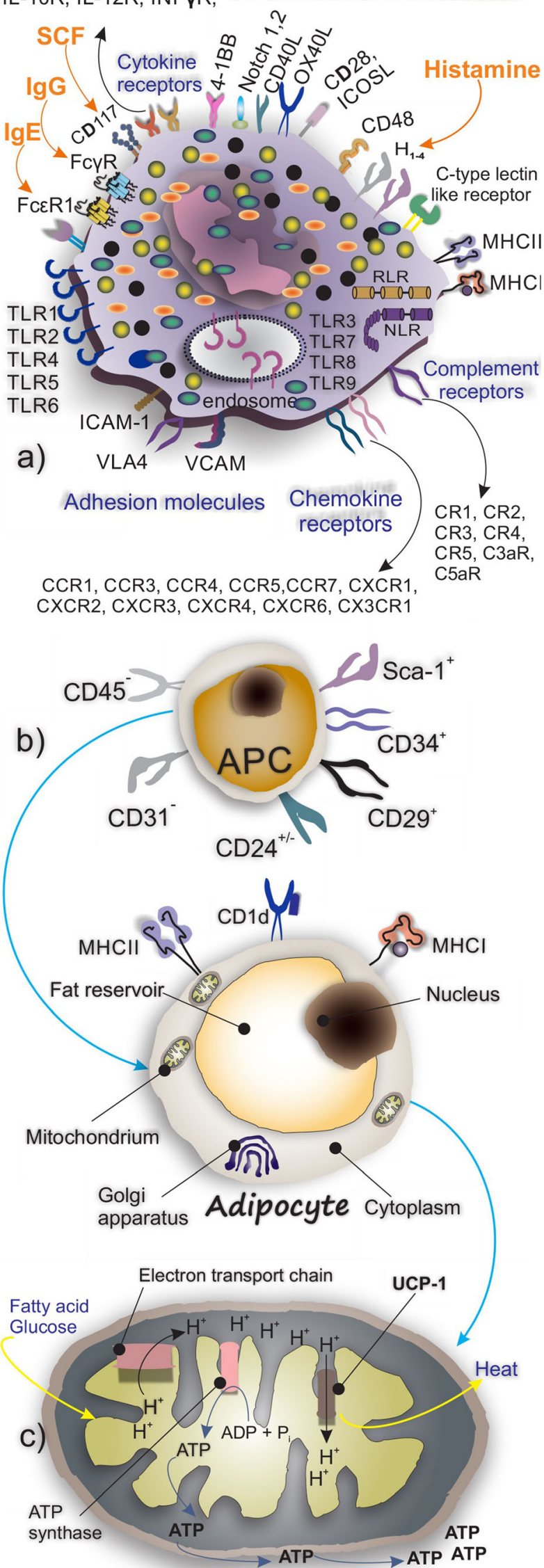

Fig. 2 a MCs express a wide spectrum of receptors for chemokines and cytokines. Their main receptors for IgG, IgE, and SCF are depicted. b Adipocytes are derived from adipocyte progenitor cells. Their main surface receptors and molecules involved in the recognition of cells are shown. $\mathbf{c}$ Molecular mechanism of UCP1 in producing heat

[17]. They produce and release three categories of molecules: (1) granule stored pre-formed mediators including histamine, heparin, tryptase, and chymase; (2) de novo synthesized mediators such as PAF, PDG2, and LTB4 and LTD4; and (3) cytokines including TNF- $\alpha$, TGF- $\beta$, IL-1, IL-3, IL-5, IL-8, and IL-10 [18]. In humans, there are two subpopulations of $\mathrm{MCs}$, namely $\mathrm{MC}_{\mathrm{TC}}$, containing tryptase, chymase, carboxypeptidase, and cathepsin that can be found in connective tissues and $\mathrm{MC}_{\mathrm{T}}$ which contain tryptase and are found mainly in the lung and gut [17] (Fig. 2a). MCs beyond their role in allergic reactions are involved in a variety of physiologic processes including angiogenesis (by releasing FGF, vascular endothelial growth factor (VEGF), and TGF- $\beta$ ) [19] and wound healing (through releasing IL-4, VEGF, and basic fibroblast growth factor (bFGF) [14]. Similar to other tissues, MCs reside in AT; however, their boosted infiltration into AT is a common finding during obesity. They promote the formation of an inflammatory milieu during obesity owing to their capability to release pro-inflammatory mediators $[20,21]$.

\section{Adipose Tissue Structure and Biology}

Although AT was initially considered an inert storage organ of fat, this view changed over the past decades. It is now defined as a highly metabolic and active tissue, which reacts to certain chemicals and produces many adipokines (acting as an endocrine organ) that regulates metabolism [22]. AT is a loose connective tissue comprised of a variety of cells mainly adipocytes which are surrounded by a matrix of collagen fibers, fibroblasts, blood vessels, and immune cells [23]. Excess caloric intake is accompanied by fat deposition and growth of adipocytes followed by activation of endoplasmic reticulum stress and orchestration of oxidative stress responses [24]. Activation of these pathways results in the production and release of proinflammatory cytokines mainly IL-6 and TNF- $\alpha$ [24]. Formation of such a pro-inflammatory environment supports the activation of resident leukocytes and the infiltration of other inflammatory cells including macrophages, neutrophils, dendritic cells, lymphocytes, and MCs [24, 25]. The ECM plays a key role in homeostasis and regulation of AT. The accumulation of ECM proteins including collagen in the early stages of obesity contributes to tissue remodeling through which fibrosis and infiltration of proinflammatory leukocytes into the AT are promoted [26]. 
AT produces a wide range of adipokines that play key roles in the regulation of glucose and lipid metabolism [27], and their dysregulation has been linked to systemic inflammation [28]. (Table 1).

AT of lean individuals produces and releases adipokines with anti-inflammatory properties mainly adiponectin and apelin while AT of obese individuals releases proinflammatory cytokines such as resistin, leptin, and visfatin [43]. Additionally, some investigations reveal the immunoregulatory properties of adipokines such as adiponectin that suppresses the activation of $\mathrm{M} 1$ macrophages while promoting the proliferation of the M2 subtype [44]. Proliferation and differentiation of preadipocytes or adipocyte progenitor cells within the stromal vascular fraction result in the formation of the new adipocytes [45]. Committed murine white adipocyte progenitors with $\mathrm{CD} 31^{-}, \mathrm{CD} 45^{-}, \mathrm{CD} 29^{+}, \mathrm{CD} 34^{+}, \mathrm{Sca}-1^{+}$, and CD $24^{+/}$ phenotype are involved in adipogenesis [45] (Fig. 2b).
Two types of AT, namely white adipose tissue (WAT) and brown adipose tissue (BAT), are known in human [23]. WAT is the main energy storage tissue, whereas, BAT dissipates energy in the form of heat and therefore plays a role in thermoregulation [46]. Both hypertrophy and hyperplasia of adipocytes are required for normal AT expansion. There is an approximately $8 \%$ rate of annual adipocyte turnover to match the rates of cell death [45]. Generally, white adipocytes act as the lipid storage units and release the stored free fatty acids during fasting periods while their counterparts brown adipocytes contribute to maintaining thermal homeostasis by burning glucose and lipids [47]. Brown adipocytes have a smaller size in comparison with white adipocytes, and their cytoplasm contains many smaller lipid droplets, a roundish nucleus and spherical mitochondria [47]. There are two distinct types of brown AT, the classical brown fat which is derived from a myf-5+ve cellular lineage and inducible brown fat that is

Table 1 List of AT-derived adipokines and their biologic functions

\begin{tabular}{|c|c|c|}
\hline Adipokine & Immunobiologic function in AT & Ref \\
\hline Leptin & $\begin{array}{l}\text { Activates CD4 T cells and induce their production of TNF- } \alpha \text {, IL- } 6 \text {, and IL-12 } \\
\text { Activates MCs and induces the release of cysLTs } \\
\text { Hypothalamic modulator of food intake, the regulator of energy expenditure } \\
\text { Upregulates monocyte activation markers including CD11b, CD11c, } \\
\text { MHC class II, CD25, CD38, and CD69 } \\
\text { Promotes neutrophil chemoattraction and the production of ROS } \\
\text { Leptin deficiency-induced obesity correlates with increased MCs in abdominal lymph nodes }\end{array}$ & $\begin{array}{l}{[29} \\
{[30} \\
{[30} \\
29 \\
{[29} \\
{[31}\end{array}$ \\
\hline Adiponectin & $\begin{array}{l}\text { The most abundant peptide secreted by adipocytes } \\
\text { Acts as a regulator of thermogenesis } \\
\text { Antagonizes TNF- } \alpha \text { expression in adipocytes and macrophages } \\
\text { Acts through AdipoR1 (mainly expressed in skeletal muscle) and AdipoR } 2 \\
\text { (predominantly expressed in the liver) } \\
\text { Promote M2 macrophage polarization and improves insulin sensitivity }\end{array}$ & $\begin{array}{l}{[23} \\
{[32} \\
{[29} \\
{[23} \\
{[33}\end{array}$ \\
\hline Lipocalin-2 (LCN2) & $\begin{array}{l}\text { Also known as neutrophil gelatinase-associated lipocalin (NGAL) } \\
\text { Upregulated in the presence of IFN- } \gamma \text { and TNF- } \alpha \text { in obese individuals }\end{array}$ & \\
\hline Retinol-binding protein 4 (RBP4) & $\begin{array}{l}\text { Promotes IR and increases the T2D risk } \\
\text { Majority of circulating RBP4 is found in complex with retinol } \\
\text { RBP is a cardiometabolic marker in chronic pathologic conditions including MetS } \\
\text { Activates APCs }\end{array}$ & $\begin{array}{l}{[34} \\
{[35} \\
{[36} \\
{[36}\end{array}$ \\
\hline Fibroblast growth factor 21 (FGF21) & $\begin{array}{l}\text { Regulates glucose and fat metabolism under fasting condition } \\
\text { It is inactivated by fibroblast activation protein alpha (FAP- } \alpha) \\
\text { Engages its receptor FGFR } 1 \text { and co-receptor } \beta \text {-Klotho } \\
\text { Involved in fatty acid oxidation and lipid metabolism improves glucose tolerance }\end{array}$ & $\begin{array}{l}{[37]} \\
{[37]} \\
{[38]} \\
{[29]}\end{array}$ \\
\hline Resistin & $\begin{array}{l}\text { Produced mainly by macrophages and acts as an inflammatory molecule } \\
\text { Secreted mainly by AT in rodents and macrophages in humans } \\
\text { Regulates the production of TNF } \alpha \text { and IL- } 6 \text { in macrophages via activation of NF- } \mathrm{kB} \text { signaling } \\
\text { Binds to TLR } 4\end{array}$ & $\begin{array}{l}{[29} \\
{[3,} \\
30 \\
30\end{array}$ \\
\hline Visfatin & $\begin{array}{l}\text { Also known as a pre-B cell colony-enhancing factor (PBEF), involved in } \\
\text { chemoattraction of neutrophils } \\
\text { Induces the production of cytokines in monocytes } \\
\text { Acts through insulin receptor- } 1 \text { and possesses hypoglycemic effect } \\
\text { Activates monocytes, promotes the secretion of IL-1 } \beta \text {, TNF- } \alpha \text {, and IL-6 }\end{array}$ & $\begin{array}{l}{[28} \\
{[27} \\
{[29}\end{array}$ \\
\hline Monocyte chemotactic protein-1 (MCP1) & $\begin{array}{l}\text { Mediated the infiltration of monocyte and macrophage to the site of inflammation } \\
\text { Its expression correlates with body BMI and adiposity }\end{array}$ & {$[4$} \\
\hline Fetuin-A & $\begin{array}{l}\text { Promotes IR by inhibition of insulin receptor's tyrosine kinase activity } \\
\text { Mainly secreted by the liver and taken up by AT } \\
\text { AT secreted fetuin-A increases in metabolic syndrome }\end{array}$ & $\begin{array}{l}{[34]} \\
{[41]} \\
{[42]}\end{array}$ \\
\hline
\end{tabular}


generated in WAT from a non-myf-5 lineage [48]. Both types of brown adipocyte express uncoupling protein 1 (UCP1) on the inner mitochondrial membrane. The brown adipocytes present in WAT are termed BRITE ("brown in white") or beige adipocytes [46]. Relatively few beige adipocytes are detected when animals are kept in normal vivarium conditions $\left(22^{\circ} \mathrm{C}\right)$. However, upon exposure to cold temperatures, the recruitment of beige adipocytes and also UCP1 increases [49]. The brownlike adipocytes in WAT depots are known for their high mitochondrial number and elevated expression of UCP1 [50] (Fig. 2c) and like classical brown fat, are able to respond to cyclic AMP [48]. Adipocytes express a variety of antigen-presenting molecules and complexes through which they mediate immune responses in other cell types, i.e., MHC I to mediate CD8 $\mathrm{T}$ cell responses, MHC II molecules for orchestration of CD4 T cell responses, and CD1d to present lipid antigens (including isoglobotrihexosylceramide, $\beta$-glucosylceramide, and plasmalogen lysophosphatidylethanolamine [51]) to iNKTs [52].

\section{Immune Cells Within the Adipose Tissue}

\section{Cells of Innate Immunity}

\section{Role of Monocytes and Macrophage Within AT}

A distinct feature of low-grade inflammation in AT is the formation of crown-like structures (CLS) which are syncytial arrangements comprised of encircled necrotic/damaged adipocytes with macrophages. The presence of CLS is associated with elevated levels of inflammatory mediators, mainly $\mathrm{TNF} \alpha$ and prostaglandin E2 [53]. Investigations have revealed that these macrophages may resorb the lipid remnants of encircled dead adipocytes and also contribute to inflammation [54]. One difference between the two types of white AT is the lower number of CLS present in subcutaneous AT compared with visceral AT both in obese and lean mice [55]. The number of $\mathrm{F} 4 / 80^{+} \mathrm{CD} 11 \mathrm{~b}^{+}$macrophages increases in obese WAT. They produce IL-6, $\mathrm{TNF} \alpha$, and metalloproteinases (MMPs) which are associated with the development of IR and establishment of an inflammatory microenvironment $[24,56]$.

Classically activated macrophages (M1) with F4/80+ $\mathrm{CD} 11 \mathrm{~b}+\mathrm{CD} 11 \mathrm{c}+\mathrm{iNOS}+$ phenotype release high levels of pro-inflammatory cytokines including TNF- $\alpha$, MCP-1, IL$1 \beta$, IL-6, IL-12, and iNOS, whereas alternatively activated macrophages (M2) having F4/80+CD11c-, CD301+, Arg1+, and CD206+ phenotype produce anti-inflammatory cytokines including IL-4, IL-10, and TGF- $\beta 1$ [29]. The M2 population is normally predominant in AT of lean mice and a shift to M1 occurs as obesity progresses [29]. Activation of the M2 population contributes to the upregulation of immunomodulatory cells, mainly Tregs [57]. Macrophage-released CXCL2 which is upregulated in obesity stimulates the adhesion of neutrophils to WAT endothelial cells and may accelerate their infiltration in AT [58]. The M2 population plays a role in clearing and removal of non-functional adipocytes from AT and mediates the recruitment of adipocyte progenitors (APs) into AT. Clinical investigations showed that CD206+ M2-like macrophages crosstalk with APs through which they participate in adipogenesis, growth/differentiation of APs, and improve insulin sensitivity [59]. Arkan et al. found a macrophage association between inflammation and insulin resistance. They generated a mouse lacking IкB kinase $\beta$ in myeloid cells including macrophages and reported that these mice have higher insulin sensitivity, suggesting that inhibition of IKK- $\beta$ may be promising in the treatment of IR [60]. Very low-density lipoprotein receptor signaling in macrophages mediates pro-inflammatory responses and supports the polarization of the M1-like phenotype, and during obesity, expression of this receptor is increased [61]. These findings support that macrophages induce inflammation in AT [61]. The recruitment of monocytes in AT is facilitated by MCP-1/CCR2 interaction [33]. Dendritic cells $\left(\mathrm{CD} 11 \mathrm{c}^{+} \mathrm{CD} 1 \mathrm{c}^{+}\right.$in human and $\mathrm{CD} 11 \mathrm{c}^{\text {high }} \mathrm{F} 4 / 80^{\text {low }}$ in mouse) have been reported to accumulate in AT during obesity and act in favor of differentiation of Th17 cells [62]. Eosinophils play a role in metabolic homeostasis by supporting the presence of M2 macrophages through releasing IL-4 and IL-13 [63]. The mechanism of action may include engaging PPAR $\gamma$ receptors expressed on M2 macrophages by eosinophil-derived IL-4 and IL-13 [63].

\section{Role of Neutrophils Within AT}

Neutrophils are among the first cells that infiltrate AT upon starting a high-fat diet (HFD) in mice [64]. They can be attracted to AT by IL-8 secreted from adipocytes and CXCL2 secreted by macrophages [24, 58]. Neutrophilsecreted elastase contributes to the polarization of M1 macrophages via TLR-4 and degrades insulin receptor substrate- 1 which leads to decreased insulin sensitivity of the AT [24]. Within the AT, neutrophils release proinflammatory cytokines including IL-8, CCL2, MMP-9, and myeloperoxidase which aggravate the inflammation state [58]. Evidence for the role neutrophil activation in obesity includes the increased expression of the activation marker CD66b and increased circulatory neutrophilreleased myeloperoxidase and calprotectin. Myeloperoxidase contributes to the development of obesity and its ablation or inhibition prevents weight gain and IR [65]. Additionally, neutrophil-released superoxides induce apoptosis and activate macrophages through which they contribute to the formation of a pro-inflammatory state [29]. Elastase among neutrophil-released mediators 


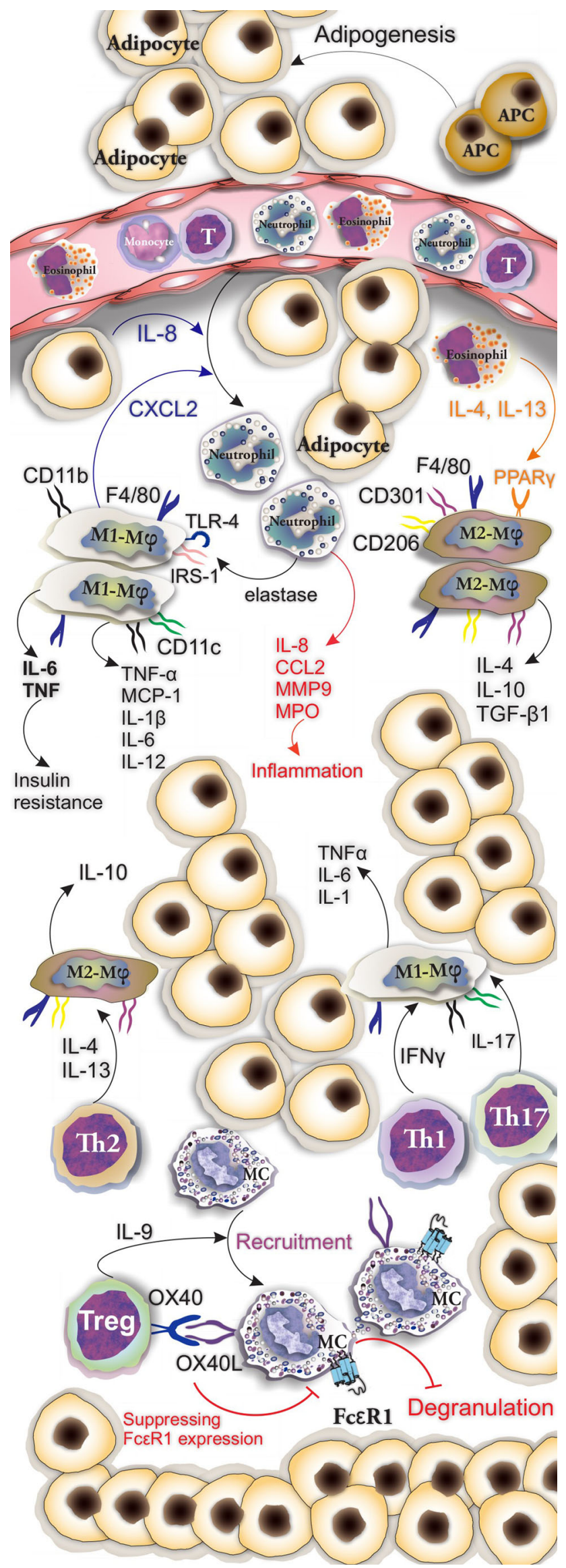

Fig. 3 Involvement of cells of innate and adaptive immunity in the orchestration of responses in AT. Inflammatory and anti-inflammatory activity of M1 and M2 macrophages are shown

is of importance in inducing IR, and inhibition of elastase improves insulin sensitivity [64].

\section{Cells of Adaptive Immunity}

Like the cells of innate immunity, orchestration of immune responses by cells of adaptive immunity determines the metabolism and biology of AT. IR is associated with increases in cell populations with a pro-inflammatory phenotype including Th1, Th17, CD8+ cytotoxic T cells, and B-2 over those cell populations with regulatory properties mainly Treg and B-1a [66]. IFN $\gamma$ and IL-17 secreted by Th1 and Th17 cells, respectively activate the pro-inflammatory functions of macrophages through the release of TNF- $\alpha$, IL-6, and IL-1. In contrast, IL- 4 and IL-13 secreted by Th2 cells induce macrophage differentiation into the anti-inflammatory IL-10 secreting M2 subset [67]. Tregs are the predominant $\mathrm{T}$ cell population in AT of lean mice; however, under HFD, their number decreases, whereas Th1 cells increase [62]. Interaction between OX40 on Treg and OX40L on MCs results in suppression of MC degranulation and FceRI expression. IL-9 produced by Tregs plays a role in the recruitment of MCs in AT [68] (Fig. 3). Feuerer et al. investigated the role of Tregs in AT and IR by inducing selective apoptosis in Tregs. For this purpose, they used diphtheria toxin receptor (DTR) expressing mice in which the DTR expression was under the control of the Foxp3 promoter. Following Tregs depletion in these mice by diphtheria toxin administration, IL-6, TNF, and RANTES expression in fat increased. They also reported elevated levels of insulin in Treg-depleted mice which could be a sign of IR [56].

\section{Adipose Tissue Residing Mast Cells}

Immunostaining of AT sections for tryptase and CD117 is a common approach used to determine the presence of $\mathrm{MC}$ populations within AT [11]. MCs with their proinflammatory profile of mediators promote the state of inflammation and participate in apoptosis and angiogenesis and may contribute to the progression of obesity and glucose intolerance via the release of IL-6 and IFN- $\gamma$ [11] (Table 2).

The MC population in adipose tissue is dynamic in nature showing changes associated with tissue remodeling in obesity. Both maturation and differentiation of MCs could occur in WAT as c-Kit ${ }^{+} \mathrm{Thy}^{-}{ }^{1}{ }^{\mathrm{lo}} \mathrm{Lin}^{-} \mathrm{Sca}^{+}$cells found in mouse subcutaneous fat pads differentiate into MMCs in vitro [22, 68]. Based on the anatomical positions of fat pads such as subcutaneous and epididymal fat, MCs show different activity and distribution [31]. For instance, visceral WAT of obese mice 
Table 2 Bio-function of MC mediators in adipose tissue biology

\begin{tabular}{lll}
\hline MC mediator & Bio-function in AT & Ref \\
\hline Chymase & Promotes angiogenesis in AT & {$[24]$} \\
IFN- $\gamma$ & Activation of AT-resident macrophages & {$[24]$} \\
MMP-9 & Activation of AT-resident macrophages & {$[24]$} \\
Tryptase & Activates PAR2 through which upregulates the expression & {$[2]$} \\
& $\quad$ of inflammatory factors, such as TNF- $\alpha$, IL-1 $\beta$, and IL-6 & \\
in endothelial cells & \\
IL-6 6 & Promotes the fibrosis in AT & {$[69]$} \\
MCP-1 & Induces the inflammation in AT & {$[8]$} \\
TNF- $\alpha$ & Induces the inflammation in AT & {$[31]$} \\
\hline
\end{tabular}

shows higher numbers of MCs compared with those of lean mice. Moreover, there is no significant difference in MC number in subcutaneous WAT between obese and lean mice [68]. Profound differences have been found when comparing MCs in the adipose tissue at morbid obesity and after bariatric surgery-induced weight loss. Surprisingly, there was a dramatic increase in the adipose resident MCs in the weight loss group with a ten-fold increase in the visceral and four-fold increase in subcutaneous adipose tissue [70]. MC-deficient mice and MC-stabilizing agents such as disodium cromoglycate have served to attempt to define the roles of AT-resident MCs in obesity and IR. Additionally, pharmaceutical reduction of MCs has been reported when pioglitazone, a PPAR $\gamma$ agonist, was applied [4, 11].

\section{Crosstalk with Cells of Adipose Tissue}

During obesity, MCs accumulate in AT where they are distributed among adipocytes or around vessels. The contribution of MCs to promote fibrosis has been investigated and their presence in fibrosis bundles and the proximity of fibrosis surrounding vessels has been reported [8]. Within AT, MCs secrete mediators that influence the immune responses of surrounding immune and non-immune cells. MC-released IFN- $\gamma$, chymase, tryptase, IL-6, and cysteinyl cathepsins are capable of activating vascular cells and adipocytes through which they support angiogenesis and differentiation of adipocytes [71]. Adipocytes release adipocytokines that may induce a series of immune responses in surrounding cells within AT. For instance, leptin acts on the leptin receptor expressed by MCs and triggers the release of mediators including cysLTs and CCL3 [30, 72]. MC mediators including IFN- $\gamma$, MMP-9, and phospholipase $\mathrm{A} 2$ regulate activation of macrophages [24]. MC-derived MCP-6 has been reported to induce collagen 5 expression in AT-resident fibroblasts and plays a role in fibrosis [69]. Prostaglandins are mediators produced by MCs and the metabolite, 15-deoxy-delta-12,14-PGJ2 (15-deoxydelta PGJ2), acts as the endogenous ligand of PPAR $\gamma$ [73].
Tanaka et al. showed that supernatants obtained from MCs activated by calcium ionophore contained 15-deoxy-delta PGJ2 which induces adipogenesis of 3T3-L1 cells and primary preadipocytes [73].

\section{Function of MC Mediators in Adipose Tissue-Lessons from Animal Models}

The observed increase in MCs in adipose tissue in obesity led to the study of their role in metabolic dysregulation associated with inflammation. Several different in vivo models have resulted in a degree of controversy with profoundly different phenotypes observed when different approaches have been taken to investigate the roles of AT-resident MCs. The involvement of MCs in obesity and IR has been investigated by the in vivo application of MC stabilizers that block degranulation and the release of mediators. Kumar et al. put C57BL/ 6 mice on HFD to initiate a progressive glucose intolerance, IR, and AT senescence [74]. Their flow cytometric results showed an interesting fluctuation in AT cellularity during the HFD diet. M1 macrophages showed a rise from nearly $1.4 \%$ of total immune cells and reached $15.7 \pm 1.5 \%$ at 20 weeks. Eosinophils, the presence of which positively correlates to insulin sensitivity showed a decrease from $8.7 \pm 1.04 \%$ at the early phase of 4 weeks to $5.6 \pm 0.6 \%$ at 16 weeks and their population restored at 20 weeks. FceRIa ${ }^{+} \mathrm{MCs}$ showed a fluctuation in which their population rose from $39.5 \pm 2.8 \%$ at 4 weeks and dropped in number to $27 \pm 1 \%$ at 12 weeks and then reached to $32.62 \pm 1.5 \%$ at 20 weeks of HFD. To investigate the role of macrophages, they were depleted using clodronate sodium liposomes (CLODs). Additionally, MCs were stabilized by disodium cromoglycate sodium liposomes (DSCGs). The strategy indicated that macrophages and MCs are involved in the progression of obesity, AT fibrosis, and glucose homeostasis [74]. A notable rise in serum glycerol level in both CLOD- and DSCG-treated mice showed the mobilization and burning of fat [74] (Fig. 4a). 
a)

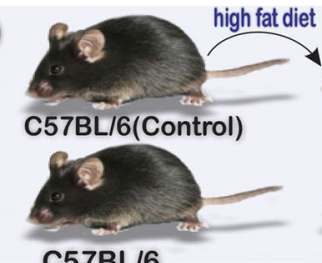

C57BL/6

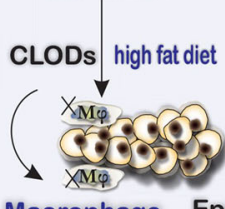

Macrophage depletion

Attenuation of: * Obesity

* AT fibrosis * Improving glucose homeostasis

b)
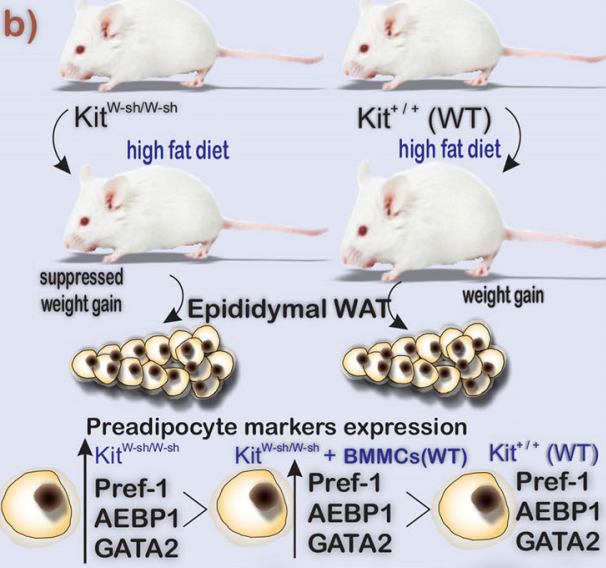

c)
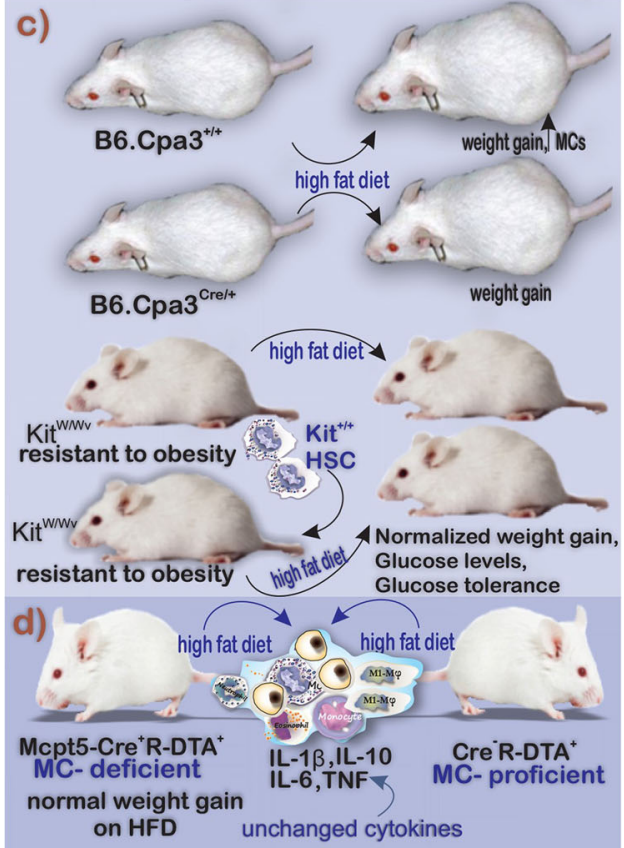

Fig. 4 Graphic summary of three animal models to show the involvement of MCs in diet-induced obesity. (WT: wild type, AT: adipose tissue, HFD: high-fat diet, HSC:hematopoietic stem cell, CLODs: clodronate sodium liposomes, DSCGs: disodium cromoglycate sodium liposomes, BMMCs: Bone marrow-derived mast cells)
Initial studies of the role of AT MCs under physiological conditions were investigated by Ishijima et al. by assessing the MC-deficient $\mathrm{Kit}^{\mathrm{W}-\mathrm{sh} / \mathrm{W}-\mathrm{sh}}$ mice [75]. These mice, due to the presence of the $\mathrm{W}$-sash $(\mathrm{W}(\mathrm{sh}))$ inversion mutation in their white spotting (W) locus, lack the normal signaling of c-kit tyrosine kinase when compared with wild-type $\mathrm{Kit}^{+/+}$mice [76]. $\mathrm{Kit}^{\mathrm{W}-\mathrm{sh} / \mathrm{W}-\mathrm{sh}}$ mice are fertile and non-anemic but histologically lack a variety of cells mainly MCs, melanocytes, and interstitial cells of Cajal [77]. Body weight gain induced by HFD was suppressed in the $\mathrm{Kit}^{\mathrm{W}-\mathrm{sh} / \mathrm{W} \text {-sh }}$ mice compared with the control group. Investigations of the levels of the preadipocyte markers Pref-1, AEBP1, and GATA2 revealed a notably higher expression in the epididymal WAT and stromal vascular fraction of the MC-deficient mice comparing with counterpart WT mice [75]. They suggested that MCs have positive effects on the transition of preadipocytes to mature adipocytes [75] (Fig. 4b). Liu et al. to provide a line of evidence on MC involvement in obesity investigated the effects of a 12-week Western diet. They concluded that $\mathrm{Kit}^{\mathrm{W}-\mathrm{sh} /}$ W-sh mice gained less weight in comparison with WT counterparts. Moreover, using intraperitoneal (i.p.) injections of DSCG, they reported the positive effects of MC stabilizer to reduce the weight gain in mice [11]. Additionally, this group investigated the role of MC mediators in obesity progression. They reconstituted $\mathrm{Kit}^{\mathrm{W}-\mathrm{sh} / \mathrm{W} \text {-sh }}$ mice with bone marrow mononuclear cells (BMMCs) prepared in vitro from WT mice and mice lacking MC cytokines IL-6 $\left(\mathrm{Il}^{-1-}\right), \mathrm{TNF}-\alpha\left(\mathrm{Tnf}^{-1}\right)$, and IFN- $\gamma\left(\mathrm{Ifng}^{-/-}\right.$) and put them on Western diet for 13 weeks. They reported that $\mathrm{Kit}^{\mathrm{W}-\mathrm{sh} / \mathrm{W}-\mathrm{sh}}$ mice reconstituted with WT and $\mathrm{Tnf}^{-/}$gained more weight when compared with nonreconstituted mice. Interestingly, $\mathrm{Kit}^{\mathrm{W}-\mathrm{sh} / \mathrm{W}-\mathrm{sh}}$ mice that received WT and $\mathrm{Tnf}^{-/-}$BMMCs were found with higher serum glucose levels, leptin, and insulin. They also reported that $\mathrm{Kit}^{\mathrm{W}-\mathrm{sh} / \mathrm{W} \text {-sh }}$ mice reconstituted with $\mathrm{Il}^{-/-}$and $\mathrm{Ifng}^{-/}$ BMMCs had improved glucose tolerance [11].

Although the initial studies using genetic mouse models with c-kit mutation indicated the involvement of MCs in obesity, several investigators have reported results that are inconsistent with these findings following the application of alternative genetic models. Gutierrez et al. found that Kit deficiency and not the lack of MCs play a central role in metabolic improvements when exposed to HFD. They highlighted the role of Kit deficiency to protect the mice from HFD-induced obesity which was due to the hematopoietic system. This group of researchers studied the role of MCs in obesity in two MC-deficient mice models, $\mathrm{Kit}^{\mathrm{W} / \mathrm{Wv}}$ (mice with deficiency in Kit) and $\mathrm{Cpa}^{\mathrm{Cre} /+}$ (mice with Kit-independent MC deficiency), and studied the process of obesity and IR after employing diet-induced obesity [78]. They first fed $\mathrm{Cpa}^{\mathrm{Cre} /+}$ and $\mathrm{Cpa}^{+/+}$(as control) with HFD and low-fat diet for 16 weeks and reported identical weight gain in each group. Investigation of AT of these mice showed that obese $\mathrm{Cpa}^{+/+}$ mice had a higher number of MCs when compared with the 
lean $\mathrm{Cpa}^{+/+}$mice. Interestingly, the reconstitution of $\mathrm{Kit}^{\mathrm{W} / \mathrm{Wv}}$ mice with $\mathrm{Cpa} 3^{\mathrm{Cre} /+}$ bone marrow could completely normalize stem and progenitor cell compartments. Additionally, $\mathrm{Kit}^{+/+}$hematopoietic transplantation could reverse all the metabolic phenotypes of the $\mathrm{Kit}^{\mathrm{W} / \mathrm{Wv}}$ mice including weight gain during HFD, baseline hyperglycemia, and loss of protection from glucose tolerance [78] (Fig. 4c). An additional model of MC deficiency has utilized a mouse line in which the Crerecombinase-dependent expression of diphtheria toxin is triggered in cells under the control of the mast cell protease (Mcpt) 5 promoter. Mcpt5-Cre ${ }^{+}$R-DTA ${ }^{+}$and Cre-negative R-DTA $^{+}$mice were subjected to HFD for 21 weeks. No difference in terms of accumulation of M1-macrophages, or upregulation of inflammatory cytokines including IL-1 $\beta$, IL-6, IL-10, and TNF, was reported. Furthermore, MC deficiency had no marked differences in obesity and obesity-related dysregulation [79]. Although MC numbers increase upon exposure to high-fat diet, the weight of evidence, taking into account the different genetic models used, indicates that the absence of these cells does not protect from obesity and IR. There are lines of evidence linking AT residing MCs to other pathologic conditions. For example, periaortic perivascular adipose tissue of patients with abdominal aortic aneurysm was shown to be populated by leukocytes including MCs. The presence and capability of MCs to produce proinflammatory mediators could aggravate the condition [80].

\section{Role of MC in AT Browning}

There is accumulating evidence supporting a role for MCs in the browning of white adipocytes. It has been found that repeated cold exposure promotes beiging of human subcutaneous WAT and it is associated with increases in adipose tissue MC recruitment [9]. Recently, Finlin et al. reported that MCs release histamine in response to cold, and this mediator induces the expression of UCP1 that is capable of uncoupling mitochondrial oxidative respiration and generating heat [81]. Such a mechanism may hamper the process of obesity by increasing energy expenditure. A study of seasonal beiging of human subcutaneous WAT identified a set of immune markers that were predictive of the UCP1 gene expression. There was a correlation with IL-4 and carboxypeptidase-A3 (CPA3), a protease that is specifically expressed by MCs [81]. As IL-4 expression was also correlated with CPA3, it could indicate that MCs may be a source of this cytokine. Importantly, in vitro studies found that $\mathrm{MC}$ degranulation and histamine release promoted UCP1 expression and stimulated lipolysis. Furthermore, histamine treatment of adipocytes potently induced UCP1 protein and mRNA along with histamine receptors. The primary mechanism of brown and beige adipocyte activation is via the sympathetic nervous system through norepinephrine action. Importantly, it has also been reported that MCs express $\beta$-adrenergic receptors and can respond to norepinephrine to degranulate and release histamine [9]. BAT is highly vascularized with a complex network of blood vessels, and when activated, there is an increase in blood flow [82]. In the rat, expression of histamine H3 receptors has been found in capillaries within BAT. This raises the possibility that histamine signaling could be involved in the regulation of thermogenesis by acting as a vasodilator on the endothelial cells [83].

A recent report has indicated that rather than having a positive effect on browning of WAT, MCs have an inhibitory role in this process. Zhang et al. studied the process of AT browning in $\mathrm{Kit}^{\mathrm{w}-\mathrm{sh} / \mathrm{w}-\mathrm{sh}}$ and MC-stabilized (WT) models which received a chow diet. They reported that $\mathrm{MC}$ inactivation induces the proliferation of adipocyte precursors with platelet-derived growth factor receptor A (PDGFR $\alpha$ ) expression, supports the beige adipocyte differentiation, and improves the thermogenesis in subcutaneous AT. Gene expression analysis showed upregulation of key brown fat genes in the subcutaneous AT of $\mathrm{Kit}^{\mathrm{w}-\mathrm{sh} /}$ w-sh mice compared with WT controls including Ucp1, Cidea, and Elovl3. Immunostaining of UCP1 of subcutaneous AT samples obtained from $\mathrm{Kit}^{\mathrm{w}-\mathrm{sh} / \mathrm{w} \text {-sh }}$ mice receiving DSCG showed that they have a higher number of $\mathrm{UCP}{ }^{+}$beige cells compared with WT mice. Moreover, considering the role of serotonin in energy balance and AT browning and that serotonin suppresses the expression of UCP1 [84], Zhang and colleagues investigated tryptophan hydroxylase 1 (TPH1) which catalyzes the production of serotonin from tryptophan in $\mathrm{Kit}^{\mathrm{w}-\mathrm{sh} / \mathrm{w} \text {-sh }}$ mice and DSCG-treated WT mice. They reported a significant suppression of the enzyme in these two models in comparison with the control group. Further investigation using WT model receiving TPH1 inhibitor (LX1031) could support their findings by showing that TPH1 inhibition increases the UCP1 expression and that serotonin is capable of inhibition of browning in subcutaneous AT [84]. The data from this study indicate that there is a profound browning of the WAT in the $\mathrm{Kit}^{\mathrm{w}-\mathrm{sh} / \mathrm{w}-\mathrm{sh}}$ mouse and this could help explain the obesity resistance of the model. However, an examination of the available microarray data on the expression of genes in AT of low-fat diet-fed $\mathrm{Kit}^{\mathrm{W} / \mathrm{Wv}}$, $\mathrm{Cpa}^{\mathrm{Cre} /+}$, and $\mathrm{Cpa}^{+/+}$(GEO: GSE67091, and analyzed using GEO2R [78]) did not reveal any differences in the levels of UCP1 or Cidea. To definitively conclude that browning is associated with loss of MCs within the AT will require further investigations using alternative genetic models that are not dependent on c-kit mutations. There is a wide range of evidence supporting the role of MCs in the browning of adipose tissue. However, further research is required to fully understand the actions of MCs in white $\mathrm{AT}$ and MC-derived histamine in BAT and beige fat activation. 


\section{Discussion and Conclusion}

MCs in addition to orchestrating the inflammatory responses in AT during the progression of obesity influence adipocyte reaction to physical changes such as beiging in response to cold to promote the thermogenesis [9]. The molecular mechanisms by which MCs respond to environmental physical changes have not been completely understood. In addition to a heterogeneous population of AT-resident cells, their interplay and similarity in expression of several receptors make AT immunobiology much more complicated. In this regard, expression of PAR2 (a G protein-coupled receptor which acts as a receptor for MC-released tryptase [14]) by not only adipocytes but also other AT-resident cells, including macrophages, makes the role of this receptor in AT biology in response to MC-released tryptase even more complex. Interestingly, even the expression levels of PAR2 vary among different strains of mice which are widely used in AT biologyrelated investigations. For example, ob/ob mice have significantly higher levels of PAR2 receptors in comparison with C57BL/6J (C57) mice [2]. Overexpression of PAR2 in AT during obesity and the possibility of blocking it by antagonists makes it a potential biomarker and pharmaceutical target in controlling obesity. In this regard, Lim et al. used GB88, a novel PAR2 antagonist in rats, and reported its benefits in attenuation of adiposity, AT inflammation, and reducing infiltration of macrophages and MCs [85]. Further investigation is needed to reveal the complex interaction of MCs and other AT-resident cells.

Recent studies aimed to clarify that the MC-adipocyte interactions have provided promising results in $\mathrm{MC}$ biology. In this regard, Paupert et al. developed a method to generate pure and functional human MCs in 3 weeks from AT. They cultured the stromal vascular fraction of AT as spheroids in serum-free medium enriched with SCF. Obtained human $\mathrm{MCs}$ were able to degranulate in the presence of IgE, C5a, substance $\mathrm{P}$, and compound $48 / 80$ and could produce prostaglandins, TNF- $\alpha$, IL- 6 , GM-CSF, chymase, tryptase, and CPA3. These AT-derived MCs had the advantages of available MC lines due to expressing FCeRI (unlike HMC-1 cells) or responding to SCF (unlike LUVA cells) [86]. MC ablation or stabilization due to the reported results may be promising strategies to control obesity and IR. There is compelling evidence implying the promising effects of using MC stabilizers in controlling obesity and induced diabetes in rodent models. However, only a small number of papers have reported such investigations in humans. In this regard, El-Haggar et al. studied ketotifen (a common MC stabilizer) in obese patients with T2D treated with glimepiride. They concluded that coadministration of ketotifen twice daily with glimepiride alleviates glycemic and inflammatory processes in treated obese individuals with T2D [87]. Additionally, the exact role of MCs in the pathology of metabolic syndrome (MetS) needs to be investigated. Most recently, Gurung et al. provided a line of evidence that subcutaneous adipose tissue (SAT) residing MCs of individuals with MetS may contribute to insulin resistance. Their results showed that the numbers of MCs (1) increase in SAT of the studied individuals and (2) positively correlate with IR in AT and the levels of glucose [88].

Although an overview of findings indicates that the absence of MCs does not prevent obesity, investigations aimed to reveal the interactions of MCs, and adipocytes show that MCs accumulate in AT of obese individuals including both mouse models and humans. Moreover, AT-resident MCs under the influence of AT-derived cytokines become activated and release pro-inflammatory cytokines that worsen the inflammatory state. Besides, MCs play a role in the remodeling of AT ECM and contribute to the recruitment of leukocytes with inflammatory activity. Further investigations are required to fully define the crosstalk between MCs and other ATresident cells and how this affects inflammation, energy homeostasis, and induction of beige adipocytes.

\section{Compliance with Ethical Standards}

Conflict of Interest The authors declare that they have no conflict of interest.

Ethical Approval This article does not contain any studies with human participants or animals performed by any of the authors.

Informed Consent No informed consent was required to prepare the manuscript.

Open Access This article is licensed under a Creative Commons Attribution 4.0 International License, which permits use, sharing, adaptation, distribution and reproduction in any medium or format, as long as you give appropriate credit to the original author(s) and the source, provide a link to the Creative Commons licence, and indicate if changes were made. The images or other third party material in this article are included in the article's Creative Commons licence, unless indicated otherwise in a credit line to the material. If material is not included in the article's Creative Commons licence and your intended use is not permitted by statutory regulation or exceeds the permitted use, you will need to obtain permission directly from the copyright holder. To view a copy of this licence, visit http://creativecommons.org/licenses/by/4.0/.

\section{References}

1. Oishi Y, Manabe I (2016) Integrated regulation of the cellular metabolism and function of immune cells in adipose tissue. Clin Exp Pharmacol Physiol 43(3):294-303. https://doi.org/10.1111/14401681.12539

2. Li M, Yang X, Zhang Y, Chen L, Lu H, Li X, Yin L, Zhi X (2015) Activation of proteaseactivated receptor2 is associated with increased expression of inflammatory factors in the adipose tissues of obese mice. Mol Med Rep 12(4):6227-6234. https://doi.org/10. 3892/mmr.2015.4179

3. Jo J, Gavrilova O, Pack S, Jou W, Mullen S, Sumner AE, Cushman SW, Periwal V (2009) Hypertrophy and/or hyperplasia: dynamics 
of adipose tissue growth. PLoS Comput Biol 5(3):e1000324. https://doi.org/10.1371/journal.pcbi.1000324

4. Spencer M, Yang L, Adu A, Finlin BS, Zhu B, Shipp LR, Rasouli N, Peterson CA, Kern PA (2014) Pioglitazone treatment reduces adipose tissue inflammation through reduction of mast cell and macrophage number and by improving vascularity. PLoS One 9(7):e102190. https://doi.org/10.1371/journal.pone.0102190

5. Lu C, Zhao AX, Gao YJ, Lee RM (2011) Modulation of vein function by perivascular adipose tissue. Eur J Pharmacol 657(13):111-116. https://doi.org/10.1016/j.ejphar.2010.12.028

6. Hotamisligil GS, Shargill NS, Spiegelman BM (1993) Adipose expression of tumor necrosis factor-alpha: direct role in obesitylinked insulin resistance. Science 259(5091):87-91

7. Kern PA, Saghizadeh M, Ong JM, Bosch RJ, Deem R, Simsolo RB (1995) The expression of tumor necrosis factor in human adipose tissue. Regulation by obesity, weight loss, and relationship to lipoprotein lipase. J Clin Invest 95(5):2111-2119. https://doi.org/10. 1172/jci117899

8. Divoux A, Moutel S, Poitou C, Lacasa D, Veyrie N, Aissat A, Arock M, Guerre-Millo M, Clement K (2012) Mast cells in human adipose tissue: link with morbid obesity, inflammatory status, and diabetes. J Clin Endocrinol Metab 97(9):E1677-E1685. https://doi. org $/ 10.1210 /$ jc. $2012-1532$

9. Finlin BS, Confides AL, Zhu B, Boulanger MC, Memetimin H, Taylor KW, Johnson ZR, Westgate PM, Dupont-Versteegden EE, Kern PA (2019) Adipose tissue mast cells promote human adipose beiging in response to cold. Sci Rep 9(1):8658. https://doi.org/10. 1038/s41598-019-45136-9

10. Bais S, Kumari R, Prashar Y, Gill NS (2017) Review of various molecular targets on mast cells and its relation to obesity: a future perspective. Diabetes Metab Syndr 11(Suppl 2):S1001-s1007. https://doi.org/10.1016/j.dsx.2017.07.029

11. Liu J, Divoux A, Sun J, Zhang J, Clement K, Glickman JN, Sukhova GK, Wolters PJ, Du J, Gorgun CZ, Doria A, Libby P, Blumberg RS, Kahn BB, Hotamisligil GS, Shi GP (2009) Genetic deficiency and pharmacological stabilization of mast cells reduce diet-induced obesity and diabetes in mice. Nat Med 15(8):940-945. https://doi.org/10.1038/nm.1994

12. Bao B, Chen YG, Zhang L, Na Xu YL, Wang X, Liu J, Qu W (2013) Momordica charantia (bitter melon) reduces obesityassociated macrophage and mast cell infiltration as well as inflammatory cytokine expression in adipose tissues. PLoS One 8(12): e84075. https://doi.org/10.1371/journal.pone.0084075

13. Dong J, Zhang X, Zhang L, Bian HX, Xu N, Bao B, Liu J (2014) Quercetin reduces obesity-associated ATM infiltration and inflammation in mice: a mechanism including AMPKalpha1/SIRT1. J Lipid Res 55(3):363-374. https://doi.org/10.1194/jlr.M038786

14. Komi DEA, Khomtchouk K, Santa Maria PL (2019) A review of the contribution of mast cells in wound healing: involved molecular and cellular mechanisms. Clin Rev Allergy Immunol:1-15. https:// doi.org/10.1007/s12016-019-08729-w

15. Elieh Ali Komi D, Rambasek T, Bielory L (2018) Clinical implications of mast cell involvement in allergic conjunctivitis. Allergy 73(3):528-539. https://doi.org/10.1111/all.13334

16. Elieh-Ali-Komi D, Cao Y (2017) Role of mast cells in the pathogenesis of multiple sclerosis and experimental autoimmune encephalomyelitis. Clin Rev Allergy Immunol 52(3):436-445. https://doi. org/10.1007/s12016-016-8595-y

17. Elieh Ali Komi D, Bjermer L (2018) Mast cell-mediated orchestration of the immune responses in human allergic asthma: current insights. Clin Rev Allergy Immunol 56:234-247. https://doi.org/ 10.1007/s12016-018-8720-1

18. Komi DEA, Rambasek T, Wohrl S (2018) Mastocytosis: from a molecular point of view. Clin Rev Allergy Immunol 54(3):397411. https://doi.org/10.1007/s12016-017-8619-2
19. Karimi A, Shahrooz R, Hobbenagh R, Delirezh N, Amani S, Garssen J, Mortaz E, M Adcock I (2020) Histological evidence for therapeutic induction of angiogenesis using mast cells and platelet-rich plasma within a bioengineered scaffold following rat hindlimb ischemia. Cell J 21(4):391-400. https://doi.org/10.22074/ cellj.2020.6287

20. Ghigliotti G, Barisione C, Garibaldi S, Fabbi P, Brunelli C, Spallarossa P, Altieri P, Rosa G, Spinella G, Palombo D, Arsenescu R, Arsenescu V (2014) Adipose tissue immune response: novel triggers and consequences for chronic inflammatory conditions. Inflammation 37(4):1337-1353. https://doi.org/10. 1007/s10753-014-9914-1

21. Elieh Ali Komi D, Ribatti D (2019) Mast cell-mediated mechanistic pathways in organ transplantation. Eur J Pharmacol 857:172458. https://doi.org/10.1016/j.ejphar.2019.172458

22. Poglio S, De Toni-Costes F, Arnaud E, Laharrague P, Espinosa E, Casteilla L, Cousin B (2010) Adipose tissue as a dedicated reservoir of functional mast cell progenitors. Stem Cells 28(11):2065-2072. https://doi.org/10.1002/stem.523

23. Achari AE, Jain SK (2017) Adiponectin, a therapeutic target for obesity, diabetes, and endothelial dysfunction. Int J Mol Sci 18(6). https://doi.org/10.3390/ijms18061321

24. Chmelar J, Chung KJ, Chavakis T (2013) The role of innate immune cells in obese adipose tissue inflammation and development of insulin resistance. Thromb Haemost 109(3):399-406. https://doi. org $/ 10.1160 /$ th12-09-0703

25. Guo H, Bazuine M, Jin D, Huang MM, Cushman SW, Chen X (2013) Evidence for the regulatory role of lipocalin 2 in high-fat diet-induced adipose tissue remodeling in male mice. Endocrinology 154(10):3525-3538. https://doi.org/10.1210/en. 2013-1289

26. Hasegawa Y, Ikeda K, Chen Y, Alba DL, Stifler D, Shinoda K, Hosono T, Maretich P, Yang Y, Ishigaki Y, Chi J, Cohen P, Koliwad SK, Kajimura S (2018) Repression of adipose tissue fibrosis through a PRDM16-GTF2IRD1 complex improves systemic glucose homeostasis. Cell Metab 27(1):180-194.e186. https://doi. org/10.1016/j.cmet.2017.12.005

27. Radzicka S, Pietryga M, Iciek R, Brazert J (2018) The role of visfatin in pathogenesis of gestational diabetes (GDM). Ginekol Pol 89(9):518-521. https://doi.org/10.5603/GP.a2018.0088

28. Koch A, Weiskirchen R (2018) Visfatin serum levels predict mortality in critically ill patients. Dis Markers 2018:7315356. https:// doi.org/10.1155/2018/7315356

29. Apostolopoulos V, de Courten MP, Stojanovska L, Blatch GL, Tangalakis K, de Courten B (2016) The complex immunological and inflammatory network of adipose tissue in obesity. Mol Nutr Food Res 60(1):43-57. https://doi.org/10.1002/mnfr.201500272

30. Zelechowska P, Agier J, Rozalska S, Wiktorska M, BrzezinskaBlaszczyk E (2018) Leptin stimulates tissue rat mast cell proinflammatory activity and migratory response. Inflamm Res 67(9):789-799. https://doi.org/10.1007/s00011-018-1171-6

31. Altintas MM, Nayer B, Walford EC, Johnson KB, Gaidosh G, Reiser J, De La Cruz-Munoz N, Ortega LM, Nayer A (2012) Leptin deficiency-induced obesity affects the density of mast cells in abdominal fat depots and lymph nodes in mice. Lipids Health Dis 11:21. https://doi.org/10.1186/1476-511x-11-21

32. Wei Q, Lee JH, Wang H, Bongmba OYN, Wu CS, Pradhan G, Sun Z, Chew L, Bajaj M, Chan L, Chapkin RS, Chen MH, Sun Y (2017) Adiponectin is required for maintaining normal body temperature in a cold environment. BMC Physiol 17(1):8. https://doi.org/10.1186/ s12899-017-0034-7

33. Anderson EK, Gutierrez DA, Hasty AH (2010) Adipose tissue recruitment of leukocytes. Curr Opin Lipidol 21(3):172-177. https:// doi.org/10.1097/MOL.0b013e3283393867

34. Satish M, Saxena SK, Agrawal DK (2019) Adipokine dysregulation and insulin resistance with atherosclerotic vascular disease: 
metabolic syndrome or independent sequelae? J Cardiovasc Trans1 Res. https://doi.org/10.1007/s12265-019-09879-0

35. Ortega-Senovilla H, de Oya M, Garces C (2019) Relationship of NEFA concentrations to RBP4 and to RBP4/retinol in prepubertal children with and without obesity. J Clin Lipidol 13(2):301-307. https://doi.org/10.1016/j.jacl.2019.01.006

36. Tabak O, Simsek G, Erdenen F, Sozer V, Hasoglu T, Gelisgen R, Altunoglu E, Muderrisoglu C, Senyigit A, Uzun H (2017) The relationship between circulating irisin, retinol binding protein-4, adiponectin and inflammatory mediators in patients with metabolic syndrome. Arch Endocrinol Metab 61(6):515-523. https://doi.org/ 10.1590/2359-3997000000289

37. Franz K, Ost M, Otten L, Herpich C, Coleman V, Endres AS, Klaus S, Muller-Werdan U, Norman K (2018) Higher serum levels of fibroblast growth factor 21 in old patients with cachexia. Nutrition 63-64:81-86. https://doi.org/10.1016/j.nut.2018.11.004

38. Mutsnaini L, Kim CS, Kim J, Joe Y, Chung HT, Choi HS, Roh E, Kim MS, Yu R (2019) Fibroblast growth factor 21 deficiency aggravates obesity-induced hypothalamic inflammation and impairs thermogenic response. Inflamm Res 68(5):351-358. https://doi.org/ 10.1007/s00011-019-01222-2

39. Benomar Y, Taouis M (2019) Molecular mechanisms underlying obesity-induced hypothalamic inflammation and insulin resistance: pivotal role of resistin/TLR4 pathways. Front Endocrinol 10:140. https://doi.org/10.3389/fendo.2019.00140

40. Sundaram S, Yan L (2019) Adipose-specific monocyte chemotactic protein-1 deficiency reduces pulmonary metastasis of Lewis lung carcinoma in mice. Anticancer Res 39(4):1729-1738. https://doi. org/10.21873/anticanres.13279

41. Khadir A, Kavalakatt S, Madhu D, Hammad M, Devarajan S, Tuomilehto J, Tiss A (2018) Fetuin-A levels are increased in the adipose tissue of diabetic obese humans but not in circulation. Lipids Health Dis 17(1):291. https://doi.org/10.1186/s12944-0180919-x

42. Jialal I, Pahwa R (2019) Fetuin-A is also an adipokine. Lipids Health Dis 18(1):73. https://doi.org/10.1186/s12944-019-1021-8

43. Makki K, Froguel P, Wolowczuk I (2013) Adipose tissue in obesityrelated inflammation and insulin resistance: cells, cytokines, and chemokines. ISRN Inflamm 2013:139239. https://doi.org/10. $1155 / 2013 / 139239$

44. Ohashi K, Parker JL, Ouchi N, Higuchi A, Vita JA, Gokce N, Pedersen AA, Kalthoff C, Tullin S, Sams A, Summer R, Walsh K (2010) Adiponectin promotes macrophage polarization toward an anti-inflammatory phenotype. J Biol Chem 285(9):6153-6160. https://doi.org/10.1074/jbc.M109.088708

45. Raajendiran A, Ooi G, Bayliss J, O’Brien PE, Schittenhelm RB, Clark AK, Taylor RA, Rodeheffer MS, Burton PR, Watt MJ (2019) Identification of metabolically distinct adipocyte progenitor cells in human adipose tissues. Cell Rep 27(5):1528-1540.e1527. https:// doi.org/10.1016/j.celrep.2019.04.010

46. Keipert S, Jastroch M (2014) Brite/beige fat and UCP1-is it thermogenesis? Biochim Biophys Acta 1837(7):1075-1082. https:// doi.org/10.1016/j.bbabio.2014.02.008

47. Giordano A, Smorlesi A, Frontini A, Barbatelli G, Cinti S (2014) White, brown and pink adipocytes: the extraordinary plasticity of the adipose organ. Eur J Endocrinol 170(5):R159-R171. https:// doi.org/10.1530/eje-13-0945

48. Wu J, Bostrom P, Sparks LM, Ye L, Choi JH, Giang AH, Khandekar M, Virtanen KA, Nuutila P, Schaart G, Huang K, Tu H, van Marken Lichtenbelt WD, Hoeks J, Enerback S, Schrauwen P, Spiegelman BM (2012) Beige adipocytes are a distinct type of thermogenic fat cell in mouse and human. Cell 150(2):366-376. https://doi.org/10.1016/j.cell.2012.05.016

49. Stine RR, Shapira SN, Lim HW, Ishibashi J, Harms M, Won KJ, Seale $\mathrm{P}$ (2016) EBF2 promotes the recruitment of beige adipocytes in white adipose tissue. Mol Metab 5(1):57-65. https://doi.org/10. 1016/j.molmet.2015.11.001

50. Deis JA, Guo H, Wu Y, Liu C, Bernlohr DA, Chen X (2019) Adipose Lipocalin 2 overexpression protects against age-related decline in thermogenic function of adipose tissue and metabolic deterioration. Mol Metab. https://doi.org/10.1016/j.molmet.2019. 03.007

51. Brennan PJ, Brigl M, Brenner MB (2013) Invariant natural killer T cells: an innate activation scheme linked to diverse effector functions. Nat Rev Immunol 13(2):101-117. https://doi.org/10.1038/ nri3369

52. Huh JY, Park YJ, Ham M, Kim JB (2014) Crosstalk between adipocytes and immune cells in adipose tissue inflammation and metabolic dysregulation in obesity. Mol Cells 37(5):365-371. https:// doi.org/10.14348/molcells.2014.0074

53. Carter JM, Hoskin TL, Pena MA, Brahmbhatt R, Winham SJ, Frost MH, Stallings-Mann M, Radisky DC, Knutson KL, Visscher DW, Degnim AC (2018) Macrophagic "crown-like structures" are associated with an increased risk of breast cancer in benign breast disease. Cancer Prev Res (Phila) 11(2):113-119. https://doi.org/10. 1158/1940-6207.Capr-17-0245

54. Murano I, Barbatelli G, Parisani V, Latini C, Muzzonigro G, Castellucci M, Cinti S (2008) Dead adipocytes, detected as crown-like structures, are prevalent in visceral fat depots of genetically obese mice. J Lipid Res 49(7):1562-1568. https://doi.org/10. 1194/jlr.M800019-JLR200

55. Altintas MM, Azad A, Nayer B, Contreras G, Zaias J, Faul C, Reiser J, Nayer A (2011) Mast cells, macrophages, and crownlike structures distinguish subcutaneous from visceral fat in mice. J Lipid Res 52(3):480-488. https://doi.org/10.1194/jlr.M011338

56. Feuerer M, Herrero L, Cipolletta D, Naaz A, Wong J, Nayer A, Lee J, Goldfine AB, Benoist C, Shoelson S, Mathis D (2009) Lean, but not obese, fat is enriched for a unique population of regulatory $\mathrm{T}$ cells that affect metabolic parameters. Nat Med 15(8):930-939. https://doi.org/10.1038/nm.2002

57. Lin J, Cai Q, Liang B, Wu L, Zhuang Y, He Y, Lin W (2019) Berberine, a traditional Chinese medicine, reduces inflammation in adipose tissue, polarizes M2 macrophages, and increases energy expenditure in mice fed a high-fat diet. Med Sci Monit 25:87-97. https://doi.org/10.12659/msm.911849

58. Rouault C, Pellegrinelli V, Schilch R, Cotillard A, Poitou C, Tordjman J, Sell H, Clement K, Lacasa D (2013) Roles of chemokine ligand-2 (CXCL2) and neutrophils in influencing endothelial cell function and inflammation of human adipose tissue. Endocrinology 154(3):1069-1079. https://doi.org/10.1210/en. 2012-1415

59. Nawaz A, Tobe K (2019) M2-like macrophages serve as a niche for adipocyte progenitors in adipose tissue. J Diabetes Investig. https:// doi.org/10.1111/jdi.13114

60. Arkan MC, Hevener AL, Greten FR, Maeda S, Li ZW, Long JM, Wynshaw-Boris A, Poli G, Olefsky J, Karin M (2005) IKK-beta links inflammation to obesity-induced insulin resistance. Nat Med 11(2):191-198. https://doi.org/10.1038/nm1185

61. Shin KC, Hwang I, Choe SS, Park J, Ji Y, Kim JI, Lee GY, Choi SH, Ching J, Kovalik JP, Kim JB (2017) Macrophage VLDLR mediates obesity-induced insulin resistance with adipose tissue inflammation. Nat Commun 8(1):1087. https://doi.org/10.1038/s41467017-01232-w

62. Bertola A, Ciucci T, Rousseau D, Bourlier V, Duffaut C, Bonnafous S, Blin-Wakkach C, Anty R, Iannelli A, Gugenheim J, Tran A, Bouloumie A, Gual P, Wakkach A (2012) Identification of adipose tissue dendritic cells correlated with obesity-associated insulin-resistance and inducing Th17 responses in mice and patients. Diabetes 61(9):2238-2247. https://doi.org/10.2337/db11-1274

63. Wu D, Molofsky AB, Liang HE, Ricardo-Gonzalez RR, Jouihan HA, Bando JK, Chawla A, Locksley RM (2011) Eosinophils 
sustain adipose alternatively activated macrophages associated with glucose homeostasis. Science 332(6026):243-247. https://doi.org/ 10.1126/science. 1201475

64. Wensveen FM, Valentic S, Sestan M, Turk Wensveen T, Polic B (2015) The "big bang" in obese fat: events initiating obesityinduced adipose tissue inflammation. Eur J Immunol 45(9):24462456. https://doi.org/10.1002/eji.201545502

65. Wang Q, Xie Z, Zhang W, Zhou J, Wu Y, Zhang M, Zhu H, Zou MH (2014) Myeloperoxidase deletion prevents high-fat diet-induced obesity and insulin resistance. Diabetes 63(12):4172-4185. https://doi.org/10.2337/db14-0026

66. Chng MH, Alonso MN, Barnes SE, Nguyen KD, Engleman EG (2015) Adaptive immunity and antigen-specific activation in obesity-associated insulin resistance. Mediat Inflamm 2015: 593075. https://doi.org/10.1155/2015/593075

67. Winer S, Chan Y, Paltser G, Truong D, Tsui H, Bahrami J, Dorfman R, Wang Y, Zielenski J, Mastronardi F, Maezawa Y, Drucker DJ, Engleman E, Winer D, Dosch HM (2009) Normalization of obesity-associated insulin resistance through immunotherapy. Nat Med 15(8):921-929. https://doi.org/10.1038/nm.2001

68. Shi MA, Shi GP (2012) Different roles of mast cells in obesity and diabetes: lessons from experimental animals and humans. Front Immunol 3:7. https://doi.org/10.3389/fimmu.2012.00007

69. Hirai S, Ohyane C, Kim YI, Lin S, Goto T, Takahashi N, Kim CS, Kang J, Yu R, Kawada T (2014) Involvement of mast cells in adipose tissue fibrosis. Am J Phys Endocrinol Metab 306(3): E247-E255. https://doi.org/10.1152/ajpendo.00056.2013

70. Garcia-Rubio J, Leon J, Redruello-Romero A, Pavon E, Cozar A, Tamayo F, Caba-Molina M, Salmeron J, Carazo A (2018) Cytometric analysis of adipose tissue reveals increments of adipocyte progenitor cells after weight loss induced by bariatric surgery. Sci Rep 8(1):15203. https://doi.org/10.1038/s41598-018-33488-7

71. Zhou Y, Yu X, Chen H, Sjoberg S, Roux J, Zhang L, Ivoulsou AH, Bensaid F, Liu CL, Liu J, Tordjman J, Clement K, Lee CH, Hotamisligil GS, Libby P, Shi GP (2015) Leptin deficiency shifts mast cells toward anti-inflammatory actions and protects mice from obesity and diabetes by polarizing M2 macrophages. Cell Metab 22(6):1045-1058. https://doi.org/10.1016/j.cmet.2015.09.013

72. Zelechowska P, Wiktorska M, Rozalska S, Stasikowska-Kanicka O, Wagrowska-Danilewicz M, Agier J, Brzezinska-Blaszczyk E (2018) Leptin receptor is expressed by tissue mast cells. Immunol Res 66(5):557-566. https://doi.org/10.1007/s12026-018-9029-0

73. Tanaka A, Nomura Y, Matsuda A, Ohmori K, Matsuda H (2011) Mast cells function as an alternative modulator of adipogenesis through 15-deoxy-delta-12, 14-prostaglandin J2. Am J Physiol Cell Physiol 301(6):C1360-C1367. https://doi.org/10.1152/ ajpcell.00514.2010

74. Kumar D, Pandya SK, Varshney S, Shankar K, Rajan S, Srivastava A, Gupta A, Gupta S, Vishwakarma AL, Misra A, Gaikwad AN (2018) Temporal immmunometabolic profiling of adipose tissue in HFD-induced obesity: manifestations of mast cells in fibrosis and senescence. Int J Obes (Lond) 43:1281-1294. https://doi.org/10. 1038/s41366-018-0228-5

75. Ishijima Y, Ohmori S, Ohneda K (2013) Mast cell deficiency results in the accumulation of preadipocytes in adipose tissue in both obese and non-obese mice. FEBS Open Bio 4:18-24. https://doi.org/10. 1016/j.fob.2013.11.004

76. Grimbaldeston MA, Chen CC, Piliponsky AM, Tsai M, Tam SY, Galli SJ (2005) Mast cell-deficient W-sash c-kit mutant Kit W-sh/ W-sh mice as a model for investigating mast cell biology in vivo.
Am J Pathol 167(3):835-848. https://doi.org/10.1016/s00029440(10)62055-x

77. Michel A, Schuler A, Friedrich P, Doner F, Bopp T, Radsak M, Hoffmann M, Relle M, Distler U, Kuharev J, Tenzer S, Feyerabend TB, Rodewald HR, Schild H, Schmitt E, Becker M, Stassen M (2013) Mast cell-deficient Kit(W-sh) "Sash" mutant mice display aberrant myelopoiesis leading to the accumulation of splenocytes that act as myeloid-derived suppressor cells. J Immunol 190(11):5534-5544. https://doi.org/10.4049/jimmunol.1203355

78. Gutierrez DA, Muralidhar S, Feyerabend TB, Herzig S, Rodewald HR (2015) Hematopoietic kit deficiency, rather than lack of mast cells, protects mice from obesity and insulin resistance. Cell Metab 21(5):678-691. https://doi.org/10.1016/j.cmet.2015.04.013

79. Chmelar J, Chatzigeorgiou A, Chung KJ, Prucnal M, Voehringer D, Roers A, Chavakis T (2016) No role for mast cells in obesity-related metabolic dysregulation. Front Immunol 7:524. https://doi.org/10. 3389/fimmu.2016.00524

80. Folkesson M, Vorkapic E, Gulbins E, Japtok L, Kleuser B, Welander M, Lanne T, Wagsater D (2017) Inflammatory cells, ceramides, and expression of proteases in perivascular adipose tissue adjacent to human abdominal aortic aneurysms. J Vasc Surg 65(4):1171-1179.e1171. https://doi.org/10.1016/j.jvs.2015.12.056

81. Finlin BS, Zhu B, Confides AL, Westgate PM, Harfmann BD, Dupont-Versteegden EE, Kern PA (2017) Mast cells promote seasonal white adipose beiging in humans. Diabetes 66(5):1237-1246. https://doi.org/10.2337/db16-1057

82. Baron DM, Clerte M, Brouckaert P, Raher MJ, Flynn AW, Zhang $\mathrm{H}$, Carter EA, Picard MH, Bloch KD, Buys ES, Scherrer-Crosbie M (2012) In vivo noninvasive characterization of brown adipose tissue blood flow by contrast ultrasound in mice. Circ Cardiovasc Imaging 5(5):652-659. https://doi.org/10.1161/circimaging.112.975607

83. Karlstedt K, Ahman MJ, Anichtchik OV, Soinila S, Panula P (2003) Expression of the $\mathrm{H} 3$ receptor in the developing CNS and brown fat suggests novel roles for histamine. Mol Cell Neurosci 24(3):614 622

84. Zhang X, Wang X, Yin H, Zhang L, Feng A, Zhang QX, Lin Y, Bao B, Hernandez LL, Shi GP, Liu J (2019) Functional inactivation of mast cells enhances subcutaneous adipose tissue browning in mice. Cell Rep 28(3):792-803.e794. https://doi.org/10.1016/j.celrep. 2019.06.044

85. Lim J, Iyer A, Liu L, Suen JY, Lohman RJ, Seow V, Yau MK, Brown L, Fairlie DP (2013) Diet-induced obesity, adipose inflammation, and metabolic dysfunction correlating with PAR2 expression are attenuated by PAR2 antagonism. FASEB J 27(12):47574767. https://doi.org/10.1096/fj.13-232702

86. Paupert J, Espinosa E (2018) Rapid and efficient production of human functional mast cells through a three-dimensional culture of adipose tissue-derived stromal vascular cells. 201(12):38153821. https://doi.org/10.4049/jimmunol.1701751

87. El-Haggar SM, Farrag WF, Kotkata FA (2015) Effect of ketotifen in obese patients with type 2 diabetes mellitus. J Diabetes Complicat 29(3):427-432. https://doi.org/10.1016/j.jdiacomp.2015.01.013

88. Gurung P, Moussa K, Adams-Huet B, Devaraj S, Jialal I (2019) Increased mast cell abundance in adipose tissue of metabolic syndrome: relevance to the proinflammatory state and increased adipose tissue fibrosis. Am J Phys Endocrinol Metab 316(3):E504e509. https://doi.org/10.1152/ajpendo.00462.2018

Publisher's Note Springer Nature remains neutral with regard to jurisdictional claims in published maps and institutional affiliations. 